\title{
ACID PHOSPHATASES IN SEEDS AND DEVELOPING SEEDLINGS OF SQUASH (CUCURBITA FICIFOLIA)
}

\author{
IRENA LORENC-KUBIS \\ Institute of Biochemistry, University of Wrocław, Tamka 2 \\ 50-137 Wrocław, Poland
}

(Received: January 18, 1994. Accepted: March 22, 1994)

\begin{abstract}
Changes in protein content and acid phosphatase activity were followed during germination (imbition through seedlings development) in extracts from cotyledons of squash (Cucurbita ficifolia). It has been shown that the activity of acid phosphatase was initially low and than increased to a maximum after 6 days of imbition. Acid phosphates were isolated from cotyledons of seeds and from 6-, 10- and 22-days old seedlings by extraction the proteins with $0.1 \mathrm{M}$ acetate buffer $\mathrm{pH} 5.1$, precipitation with ethanol and by affinity chromatography on con A-Sepharose. Two glycoprotein enzymes AcPase Ba and AcPase $\mathrm{Bb}$ which differ in their affinity to immobilized con A were obtained. Both acid phosphatates retained the enzyme activity after binding to free con $\mathrm{A}$. Rocket affinity electrophoresis of AcPase $\mathrm{Ba}$ and $\mathrm{AcPase} \mathrm{Bb}$, isolated from cotyledons of seeds and seedlings, revealed differences in their ability to bind to con A during seeds germination and seedling development indicating changes in their sugar component. Con A was found to activate both enzymes. The enzymes cross-reacted with monospecific antibodies raised against grass seed acid phosphatate $\mathrm{Ba}$ indicating an antigenic relationship between squash and grass acid phosphatases.
\end{abstract}

KEY WORDS: Acid phosphatase, con A-binding, cotyledons, Cucurbitaceae, glycoproteins, immunological relationship.

\section{INTRODUCTION}

Seed germination involves the loss of stored reserves from the embryonic cotyledons as the root-shoot axis of the young seedling expand. During the germination the activity of various proteins changes (Bøg-Hansen et al. 1974; Harley and Beevers 1986; Moris et al. 1985, Wilimowska-Pelc et al. 1991) which may indicate a regulatory function of these proteins in the biochemical mechanism of germination. Earlier it has been shown that acid phosphatase activity changes during germination of seeds (Karczewska et al. 1987; Teno et al. 1987) and that the level of enzyme activity in grass seeds is related strictly to their germination ability (Lorenc-Kubis and Morawiecka 1984).

Acid phosphatates which occur in seeds and tissues of higher plants are glycoproteins (Kruzel and Morawiecka 1982; Lorenc-Kubis and Morawiecka 1980; Ferens and Morawiecka 1985) and bind to lectins (Lorenc-Kubis and BøgHansen 1981; Lorenc-Kubis and Morawiecka 1986).

Rocket affinity electrophoresis with con A revealed that AcPases isolated from seeds and tissues of grass seedlings (Lorenc-Kubis and Morawiecka 1986) and blue lupine (Lorenc-Kubis 1989) differ in their ability to bind to free con A, what may reflect changes in their sugar component.

Abbrevations used: AcPase - acid phosphatase; p-NPP-p - nitrophenyl phosphate; PAGE - polyacrylamide gel electrophoresis; Con A - concanavalin A. LcA - Lens culinaris agglutinin; WGA - wheat germ agglutinin; SBA - soy bean agglutinin.
Very little is known about acid phosphatases in germinating seeds and developing seedlings of Cucurbitaceae. Thus, the temporal changes in squash (Cucurbita ficifolia) cotyledonary protein content and acid phosphatase activity during seed germination and seedling development have been investigated.

Besides, studies on some properties of isolated AcPases, their interaction with lectins have been undertaken.

\section{MATERIALS AND METHODS}

\section{Plant material}

The study was carried out on seeds and seedlings of squash (Cucurbita ficifolia). Seeds were sterilized by soaking them in $90 \%$ acetone for $5 \mathrm{~min}$ then in $30 \% \mathrm{H}_{2} \mathrm{O}_{2}$ for $10 \mathrm{~min}$ and washed with distilled water according to Piche et al. (1985). The seeds were sown in a moist germination bed of filter paper and allowed to germinate at $22-24^{\circ} \mathrm{C}$ for $22 \mathrm{~d}$ with 10 $12 \mathrm{~h}$ of daily light. No fungal contamination was observed on the germinating seeds. The seedlings were harvested after 3-, 6-, $10-$ and $22-\mathrm{d}$ and the cotyledons of seedlings were dissected.

\section{Extraction of acid phosphatase}

Ground cotyledons of dry seeds and cotyledons of 3-, 6-, 10 - and 22-d old seedlings were homogenized with 3 vols (w/v) of $0.1 \mathrm{M}$ sodium acetate buffer, pH 5.1 at $40{ }^{\circ} \mathrm{C}$ and extracted for $1 \mathrm{~h}$ with constant mechanical stirring. After centrifugation $(12000 \times \mathrm{g}, 30 \mathrm{~min})$ the pellet was discarded and the supernatant was used for purification of acid phosphatase. 


\section{Ethanol-precipitation}

The proteins were precipitated with ethanol to a final concentration of $60 \%$. The process was carried out at $-20{ }^{\circ} \mathrm{C}$. Cooled ethanol was gradually added to the supernatant with constant stirring. After being kept at this temperature for 24 $\mathrm{h}$, the mixture was centrifuged at $6000 \times \mathrm{g}$ for $20 \mathrm{~min}$. The precipitate was suspended in $0.1 \mathrm{M}$ sodium acetate buffer, $\mathrm{pH}$ 5.6 and dialyzed against this buffer. After $24 \mathrm{~h}$ solid material was removed by centrifugation at $12000 \times \mathrm{g}$ for $20 \mathrm{~min}$ and an equal volume of $0.1 \mathrm{M}$ acetate buffer, $\mathrm{pH} 5.6$ containing 2 $\mathrm{M} \mathrm{NaCl}$ and $\mathrm{Mg}^{2+}, \mathrm{Mn}^{2+}, \mathrm{Ca}^{2+}$ (chloride forms) at $2 \mathrm{mM}$ concentration was added.

\section{Affinity chromatography}

Affinity chromatography was carried out at room temperature as described earlier (Lorenc-Kubis 1989). The material was applied to a Con A-Sepharose column $(10 \mathrm{~cm}$ long, $3 \mathrm{~cm}$ i.d; Pharmacia Uppsala, Sweden) equilibratet with $0.1 \mathrm{M}$ acetate buffer, pH 5.6 containing $1 \mathrm{M} \mathrm{NaCl}$ and $\mathrm{Mg}^{2+}, \mathrm{Mn}^{2+}$, $\mathrm{Ca}^{2+}$ at $1 \mathrm{mM}$ concentration. The proteins not adsorbed on the column were removed by washing with the same buffer. The active boun proteins were displaced from the column with $15 \mathrm{mM}$ and $300 \mathrm{mM} \alpha$-methyl-D-mannopyranoside (Sigma, USA). Active fractions were pooled and dialysed against water and concentrated by ultrafiltration, or in the stream of cold air.

\section{Ion-exchange chromatography}

The active fractions eluted from con A-Sepharose column with $15 \mathrm{mM}$-(AcPase Ba) and $300 \mathrm{mM}$-methyl-D- mannopyranoside (AcPase $\mathrm{Bb}$ ) were dialysed against $0.05 \mathrm{M}$ acetate buffer, ph 4.6 and than subjected to chromatography on SPSephadex C-50 (15 cm long, $3 \mathrm{~cm}$ i.d.; Pharmacia, Uppsala, Sweden) equilibrated with the same buffer. The proteins were eluted with increasing $\mathrm{NaCl}$ concentration $(0.05$ to $1.0 \mathrm{M})$. The enzymes were eluted from the column with $0.1 \mathrm{M} \mathrm{NaCl}$ and $0.5 \mathrm{M} \mathrm{NaCl}$ in $0.05 \mathrm{M}$ sodium acetate buffer, ph 4.6.

\section{Analysis of acid phosphatases}

Acid phosphatase activity was measured as described in Ferens et al. (1985) using $5 \mathrm{mM}$ p-NPP as sustrate in total volume of $2 \mathrm{ml}$. The amount of $\mathrm{p}-\mathrm{NP}$ was measured spectrophotometrically at $410 \mathrm{~nm}$. One unit of enzyme activity was defined as the amount of acid phophatase releasing $1 \mu \mathrm{Mol}$ of p-NP at pH 5.1 at $37{ }^{\circ} \mathrm{C}$ after $1 \mathrm{~min}$.

Lectin-acid phosphatase interaction experiments were performed with $1-5 \mu \mathrm{g} / \mathrm{ml}$ of enzyme and $10-50 \mu \mathrm{g} / \mathrm{ml}$ of Con A (Pharmacia, Uppsala, Sweden) as in Lorenc-Kubis (1989).

Double affinity diffusion with free lectins: Con A, LcA, SBA and WGA was performed in $10 \mathrm{mg} / \mathrm{ml}$ agarose gel $(\mathrm{pH} 8.6)$. The lectins $(10 \mu \mathrm{l}$ of $10 \mathrm{mg} / \mathrm{ml})$ were placed in the outside wells, and the acid phosphatase $(10 \mu \mathrm{l}$ of $1 \mathrm{mg} / \mathrm{ml})$ was placed in the centre well. The diffusion took place during $48 \mathrm{~h}$.

Rocket affinity electrophoresis was performed according to Bøg-Hansen et al. (1977).

Polyacrylamide gel electrophoresis (PAGE) was performed by the method of Davis (1964) at pH 8.3 in $12 \%$ gel. Samples containing 20-100 $\mu \mathrm{g}$ proteins of crude extracts of cotyledons were subjected to electrophoresis. Gels were stained for proteins with $0.4 \%$ Coomassie brilliant blu R-250 in 50\% TCA. For detection of acid phosphatase activity the gel was soaked in $0.2 \mathrm{M}$ acetate buffer, $\mathrm{pH} 5.1$ for $20 \mathrm{~min}$ and then incubated at $37^{\circ} \mathrm{C}$ in $0,1 \mathrm{M}$ acetate buffer, pH 5.1 containing $0.1 \%$ so- dium $\alpha$-naphthyl phosphate and $0.04 \%$ Fast blue B (until the transparent zones were visible). Then the gels were soaked in $7 \%$ acetic acid.

The Immunodiffusion test was performed according to Ouchterlony (1967).

Protein precipitates were stained on washed and dried immunoplates (Axelsen et al. 1973) with Coomassie brilliant blue R-250. Acid phosphatase activity was revealed on the plates by the diazocoupling method. The washed and dried plates were incubated at $37^{\circ} \mathrm{C}$ in $0.1 \mathrm{M}$ acetate bufer, pH 5.1 containing $1 \mathrm{mg} / \mathrm{ml}$ sodium $\alpha$-naphthyl phosphate as substrate and $0.4 \mathrm{mg} / \mathrm{ml}$ Fast Blue B salt. The acid phosphatase activity in the immunodifusion test, was revealed on the plates before staining for protein.

Antibodies were purified from rabbit antiserum raised against purified acid phosphatase $\mathrm{Ba}$ from seeds of meadowgrass (Poa pratensis L.) according to Harboe and Ingild (1973)

Protein was estimated by the method of Lowry et al. (1951), and spectrophotometrically at $280 \mathrm{~nm}$.

\section{RESULTS AND DISCUSSION}

\section{Acid phopshatase activity during seeds germination and development of seedlings}

Protein from cotyledons of dry and imbibed seeds and cotyledons of 3-, 6-, 10- and 22-d old seedlings were extracted with $0.1 \mathrm{M}$ acetate buffer, $\mathrm{pH} 5.1$ and the acid phosphatase activity was monitored during germination and seedlings development. The curves showing protein content, and acid phosphatase activity in cotyledons as a function of germination days are shown in Fig 1. It has been shown that the AcPase activity

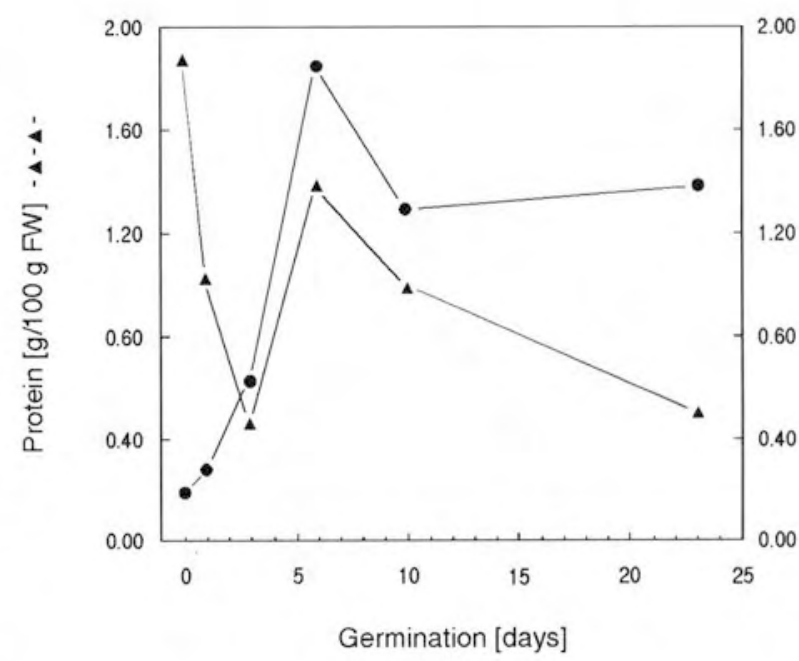

Fig.1. Changes in protein content (- $\mathbf{\Delta - \mathbf { \Delta } - )}$ ) and acid phosphatase activity (--) of cotyledons during seeds germination and seedlings development of squash (Cucurbita ficifolia).

Proteins of cotyledons were extracted with $0.1 \mathrm{M}$ acetate buffer $\mathrm{pH}$ 5.1. Acid phosphatase activity was measured in crude extracts in conditions described in Material and methods. The data are means of five replications. 
was relatively low at the onset of germination and than increased about 9-fold to a peak on day 6 and fell down on day 10. These results allowed to establish the time of maximum of acid phosphatase activity during germination and hence to optimize the extraction procedure. Changes in acid phosphatase activity have been demonstrated during plant growth and development (Baker and Takeo 1973, Bøg-Hansen et al. 1974, Ching et al. 1984; Tamura et al. 1982). Mioduszewska et al. (1984) described an increase of acid phopshatase activity during potato bulb maturation and completion of respose state.

\section{Electrophoretical analysis}

The proteins from crude extracts of seed cotyledons and developing seedlings were electrophoresed on polyacrylamide gel (PAGE), pH 8.6 and stained for proteins and acid phosphatase activity. The data are shown in Fig. 2. In extracts from cotyledons of dry seeds acid phopshatase activity was not detectable in these conditions or only a trace band with a low mobility was shown. This may suggest that in dry seeds the enzyme is bound to the other proteins and is hardly soluble in acetate buffer. In extracts of cotyledons from 3- and 6-d old seedlings after imbibition one major and two minor bands of enzyme activity appeared. In 22-d old seedlings one more band with a low mobility appeared.

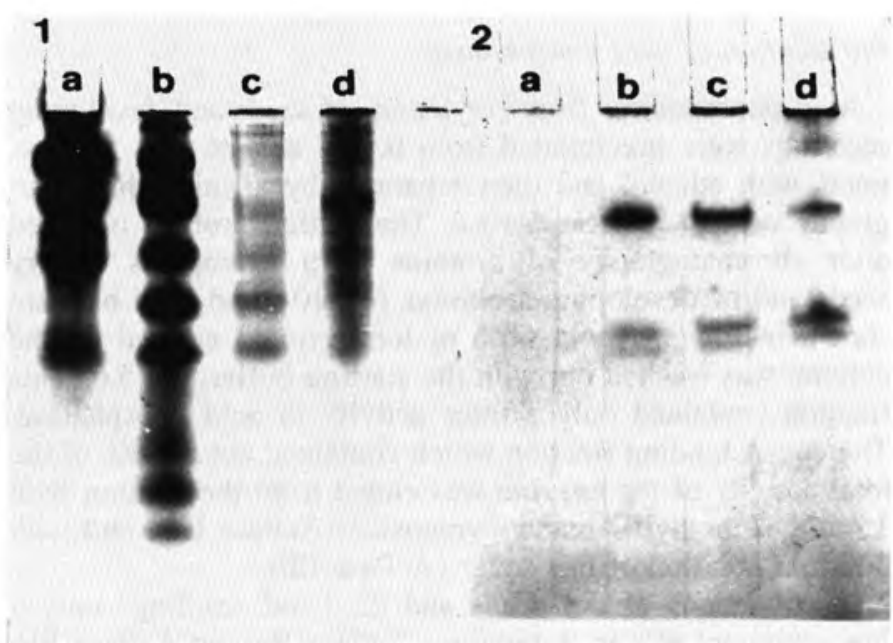

Fig.2. Polyacrylamide gel electrophoresis of cotyledon proteins and acid phosphatase during growth of squash seedlings.

The proteins $(20-100 \mu \mathrm{g})$ were run in $12 \%$ gel at $\mathrm{pH} 8.3$ according to Davis (1964), The gel was devided into two parts. One part was stained with Coomassie brilliant blue $\mathrm{R}-250$ (1): the other for acid phoshatase activity (2) (incubation at $37{ }^{\circ} \mathrm{C}$ in $0.2 \mathrm{M}$ acetate buffer pH 5.1 containing $0.1 \%$ sodium $\alpha$-naphthyl phosphate and $0,04 \%$ Fast Blue B). a) -dry seeds; b) -6-d; c) -10-d; and d) -22-d old seedlings.
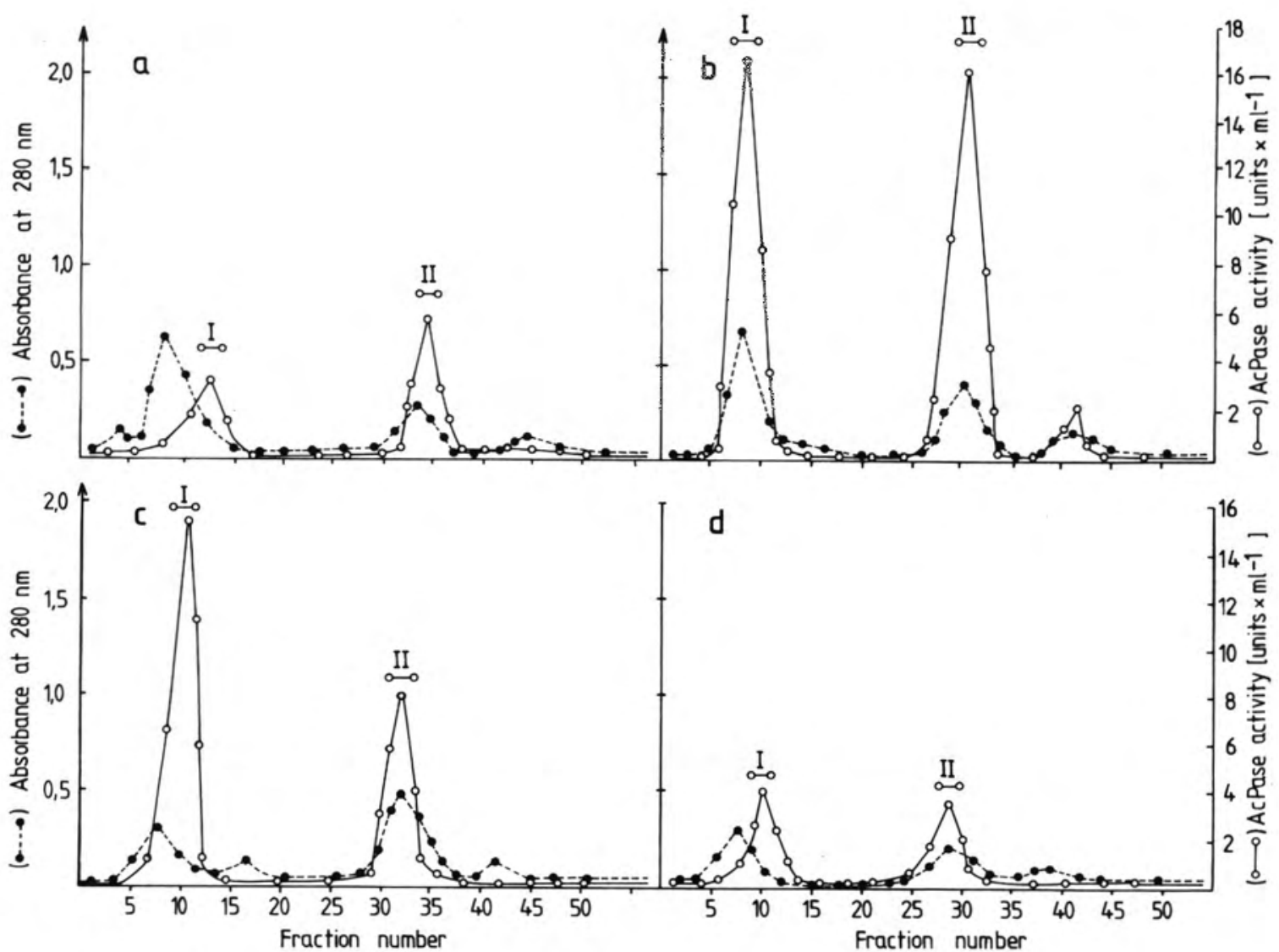

Fig.3. Affinity chromatography on con A-Sepharose of acid phopshatase from cotyledons of: dry seeds (a), 6-d (b), 10-d (c), 22-d old seedlings from squash (d).

The dialised ethanol precipitated proteins (60-100 mg) were applied to con A-Sepharose column (10 $\mathrm{cm}$ long, 3.0 i.d.) equilibrated with $0.1 \mathrm{M}$ acetate buffer $\mathrm{pH} 5.6$ containing $1 \mathrm{M} \mathrm{NaCl}$ and $\mathrm{Mg}^{2+}, \mathrm{Mn}^{2+}, \mathrm{Ca}^{2+}$ at $1 \mathrm{mM}$. The adsorbed proteins were eluted from the column with $15 \mathrm{mM}-$ and $300 \mathrm{mM}-\alpha$-methyl D-mannopyranoside in acetate buffer $\mathrm{pH}$ 5.6. Fractions of $3 \mathrm{ml}$ were collected. The bars indicate the pooled fractions (o--o). Optical density at $280 \mathrm{~nm},(\bullet--\bullet)$; acid phosphatase activity, (o---o); AcPase Ba (I), AcPase Bb (II). 


\section{Purification of acid phosphatase}

Acid phosphatases from cotyledons of seeds and developing seedlings were precipitated from $0.1 \mathrm{M}$ acetate ( $\mathrm{pH} 5.1$ ) extracts with ethanol and then separated by affinity chromatography on con A - Sepharose. The elution profiles obtained after chromatography of proteins from coleoptiles of dry seeds and of developing seedlings (6-, 10-, and 22-d old) are shown in Fig 3. About $60 \%$ of total protein applied on the column was washed out with the starting buffer, $\mathrm{pH}$ 5.6. This fraction contained only a trace activity of acid phosphatase. The con A binding fraction which contained about $90 \%$ of the total activity of the enzyme was eluted from the column with $15 \mathrm{mM} \alpha$-methyl-D-mannopyranoside (AcPase Ba), and with $300 \mathrm{mM}$ solution of this sugar (AcPase Bb).

In cotyledons of dry seeds and 22-d old seedlings only a low ammount of con $\mathrm{A}$ binding (AcPase $\mathrm{Ba}$ and AcPase $\mathrm{Bb}$ ) could be detected.

It was shown that during the development of seedlings changes in the activity of AcPase $\mathrm{Ba}$ and $\mathrm{Bb}$ occured. In cotyledons of dry seeds the activity of AcPase $\mathrm{Bb}$ was higher than the AcPase Ba while in cotyledons of 10-d old seedlings the activity of AcPase $\mathrm{Ba}$ was more than 2 times higher than that of AcPase Bb. In 6-, and 22 days old seedlings both enzymes have shown similar activity. The highest activity of acid phosphatase $\mathrm{Ba}$ and $\mathrm{Bb}$ was found in cotyledons of 6-d old seedlings. The differences in activity between the two forms of AcPase $\mathrm{Ba}$ and $\mathrm{Bb}$ may reflect some changes occuring in the molecular forms of these enzymes during seedlings development. These enzymes were further purified by ion-exchange chromatography on SP-Sephadex. The AcPases Ba and $\mathrm{Bb}$ were eluted from the column with $0.1 \mathrm{M}$ and $0.5 \mathrm{M}$ $\mathrm{NaCl}$ in $0.05 \mathrm{M}$ sodium acetate buffer, $\mathrm{pH}$ 4.6.

\section{Interaction of AcPase $\mathrm{Ba}$ and $\mathrm{Bb}$ with lectins}

Both cotyledonary enzymes from all stages of development interact with free con A and form an affinity precipitate indicating that the carbohydrate part of enzymes contains exposed mannose or glucose units. Moreover the enzymes were activitated by binding to con $\mathrm{A}$. The increase of activity ranges between 50 to 80 per cent. The activitation was reversible with addition of specific sugar inhibitors of lectin binding.

It has been shown earlier that some acid phopshatases change their properties after interaction with lectins (LorencKubis and Bøg-Hansen 1981; Lorenc-Kubis et al 1981; Ferens and Morawiecka 1985a; Morawiecka and Arabska 1982). The effect of lectins on the enzyme activity suggests a protective action of lectins perhaps by stabilizing the conformation of the enzyme (Lorenc-Kubis et al. 1981).

Rocket-affinity electrophoresis with free con A showed differences in the morphology and staining intensity between the affinty percipitates of AcPase $\mathrm{Ba}$ and $\mathrm{Bb}$ isolated from cotyledons of seedings from different stages of development (Fig. 4). The affinity precipitate of AcPase Ba from cotyledons of dry seeds was very weak, whereas the enzyme isolated from 6-, 10- and 22-d old seedlings formed a distinct precipitate with free con A. A distinct affinity precipitate was formed also in the case of AcPase Bb isolated from cotyledons of 6-, and 10$\mathrm{d}$ old seedlings. In the case of AcPase Bb from 22-d seedlings only a small precipitate was found. The differences in morphology and staining intensity of rocket-affinity precipitates of AcPase $\mathrm{Ba}$ and $\mathrm{Bb}$ may reflect changes in the sugar component of the enzymes during the germination of seeds and development of seedlings.
A

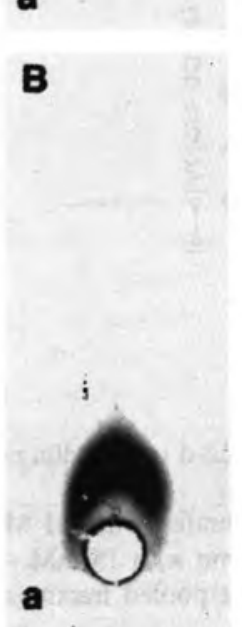

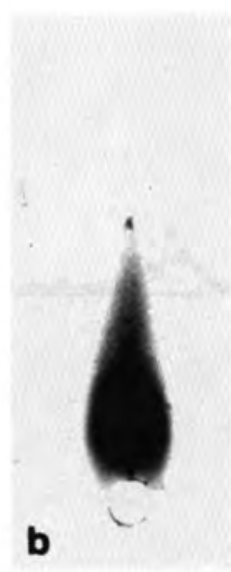

(1)

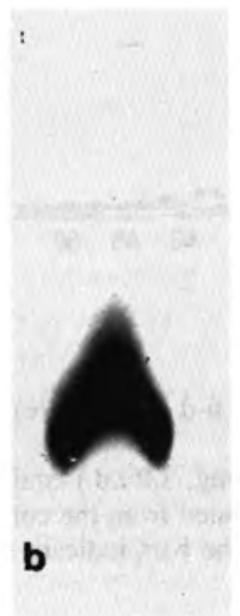

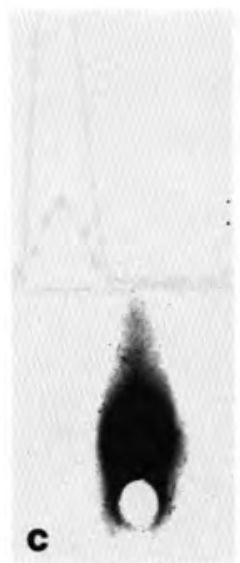

d
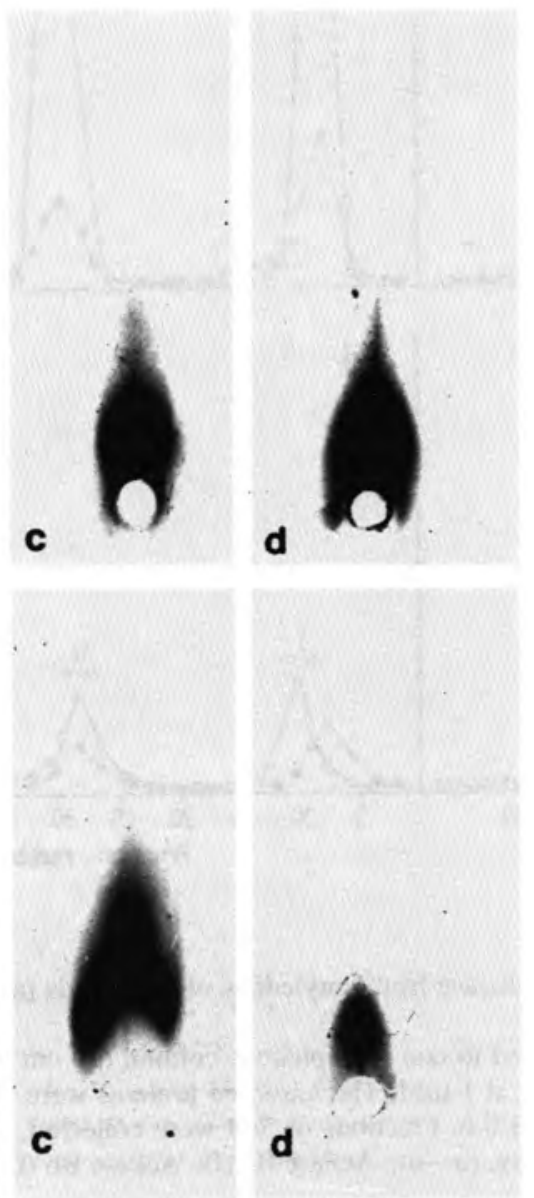

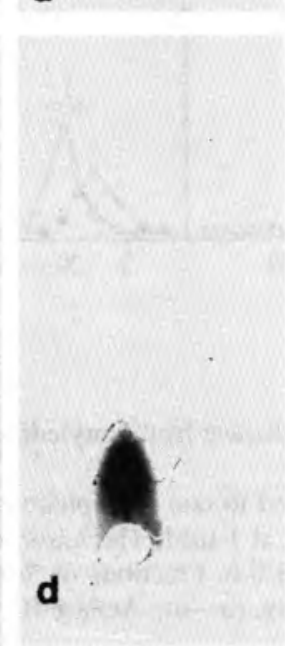

Fig. 4. Rocket affinity electrophoresis of $10 \mu \mathrm{g}$ of acid phosphase $\mathrm{Ba}(\mathrm{A})$ and $\mathrm{Bb}$ (B) of cotyledons from: seeds (a) and seedlings 6-d (b),10-d (c), and 22-d old (d) into $10 \mathrm{mg} / \mathrm{ml}$ agarose gel containing con A 50 $\mu \mathrm{g} / \mathrm{cm}^{2}$. After electrophoresis the plates were washed and dried and acid phosphatase $\mathrm{Ba}$ and $\mathrm{Bb}$ were revealed by incubating the plates in $0.1 \mathrm{M}$ acetate buffer $\mathrm{pH} 5.1,37{ }^{\circ} \mathrm{C}$ containing $0.1 \%$ sodium $\alpha$-naphthyl phosphate and $0.04 \%$ Fast Blue B (until the transparent affinity precipitates were visible). Then the plates were washed with water and dried. 
Immunological ralationship of squash acid phosphatases with grass AcPases

The acid phosphatase $\mathrm{Ba}$ and $\mathrm{Bb}$ from cotyledons of 6-d old seedlings was analysed by double immunodiffusion using antibodies raised against meadow-grass (Poa pratensis L.) Ac Pase $\mathrm{Ba}$. Figure 5 shows the results of this test. Both enzymes formed an immunoprecipitate which showed acid phosphatase activity. The enzyme activity was revealed before staining for protein, which demonstrates that the same precipitation band represents both protein and enzyme activity. After interaction

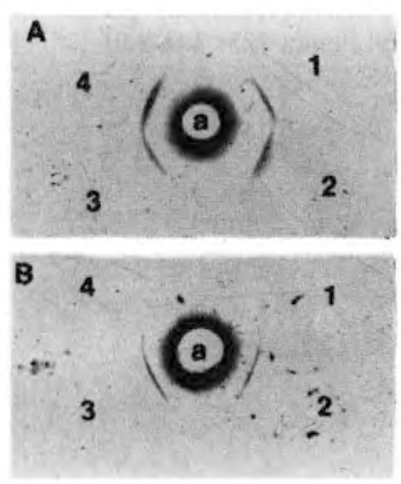

Fig.5. Ouchterlony immunodiffusion of acid phosphatase $\mathrm{Ba}(\mathrm{A})$ and $\mathrm{Bb}(\mathrm{B})$ from squash cotyledons against anti-seeds acid phopshatase $\mathrm{Ba}$ of meadow-grass (Poa pratensis) antibodies.

The precipitates were first stained for acid phosphatase activity and then for protein with Coomassie brilliant blue R-250 on the washed and dried plates.

Antibodies were applied in the central well (a). The peripheral wells were filled with AcPase of: dry seeds, (1) and seedlings: 5-d (2),10d (3) and. 22-d old.(4).

with antibodies the AcPase remain fully active, what leads to the conclusion that the substrate-binding region is placed beyond the area of antigenic determinants. The cross-reaction of AcPases $\mathrm{Ba}$ and $\mathrm{Bb}$ with antibodies raised against acid phosphatase $\mathrm{Ba}$ from meadow-grass suggests that the enzymes from cotyledons of squash (Cucurbita ficifolia) and grass seeds have common antigenic sites. Earlier studies on immunological ralationship of grass acid phosphatases (LorencKubis 1986; Lorenc-Kubis and Morawiecka 1985) and AcPases isolated from blue lupine (Lupinus angustifolius L.) (Lorenc-Kubis 1989) have shown that the enzymes are immunologically related proteins.

The immunological ralationship between acid phosphatases from mono- and dicotyledons and the changes in enzyme activity in the presence of lectins may indicate that both of the proteins with a high degree of conservation may play an important matabolic function in plants.

\section{ACKNOWLEDGEMENTS}

The author thanks Professor Dr. hab. Bronisława Morawiecka for her helpful discussion and for rewieving the manuscript; Renata Herba and Małgorzata Dobaczewska for exellent help in the preparation of the enzyme. I am grateful to Dr. Zofia Olichwier for developing my interest in germination of squash (Cucurbita ficifolia) seeds.

This study was supported by K.B.N. grant, No 4047/PB/Bch/93.

\section{LITERATURE CITED}

AXELSEN N. H., KROLL J., WEEKE B., 1973. A manual of quantitative immuno-electrophoresis. Methods applications. Scand. J. Immunol. 2, Suppl. 1, 1-169.

BAKER J.E., TAKEO T.,1973. Acid phosphatase in plant tissues: I. Changes in activity and multiple forms in tea leaves and tomato fruits during maturation and senescence. Plant Cell Physiol.14: 459-471

BØG-HANSEN T. C., LARSSON O. M., ORY R. L.,1974. Phosphatase activities in barley. Investigation of some properties and activity changes during germination. Bios. 9: 334-337

BØG-HANSEN T. C., BJERRUM O.J., BROGREN C.-H.,1977. Identification and quantification of glycoproteins by affinity electrophoresis. Anal. Biochem. 81: 78-87

CHING T.M., THOMPSON D.M., METZGER R.,1984. Acid phosphatases and seed shiveling in Triticale. Plant Physiol. 76: 478-482.

DAVIS B.J., 1964. Disc electrophoresis Il. Method and application to human serum proteins. Ann. N. Y. Acad. Sci.121: 404-427

FERENS M., MORAWIECKA B.,1985. Rye germ acid phosphatase; properties of the enzyme and its activation by lectins. Phytochemistry $24: 2839-2842$

FERENS M., MORAWIECKA B.,1985a. Lectin involved in plant mobilization of seed reserves ? Rye germ agglutinin (RGA) activate the endogenous acid phosphatase. In: Lectins-Biology, Biochemistry, Clinical Biochemistry, vol. 4: Bøg-Hansen,T,C., Bręborowicz J. eds Walter de Gruyter, Berlin, New York pp. 515-522

HARLEY S.M., BEEVERS H.,1986. Lectin in castor bean seedlings. Plant Physiol. 80: 1-6.

HARBOE N., INGILD A.,1973. Immunization, isolation of immunoglobulins, estimation of antibody titre Scand. J. Immunol. 2: Suppl. 1,161-164.

KARCZEWSKA J., FERENS-SIECZKOWSKA M., MORAWIECKA B.,1987. Izozymy fosfatazy kwasnej w kiełkujących ziarniakach żyta. XXIII Meet., Pol. Biochem. Soc. Białystok Abstr. p. 112.

KRUZEL M., MORAWIECKA B., 1982. Acid phosphatase of potato tubers (Solanum tuberosum). Purification,properties,sugar and amino acid composition. Acta Biochim. Polon. 29: 321-330

LORENC-KUBIS I. 1986. Some properties and immunological relationship of acid phosphatase from Gramineae. Plant Science 44: 1-5

LORENC-KUBIS I., 1989. Acid phosphathases from Lupinus angustifolius and their immunological relationship with grass acid phosphatases. Plant Science, 62: 37-43.

LORENC-KUBIS I., MORAWIECKA B,. 1980. Purification and some properties of the main polymorphic form of acid phosphatase from Poa pratensis seeds. Acta Biochim. Polon. 27: 345-352

LORENC-KUBIS I. , BØG-HANSEN T. C. ,1981. Activation of acid phosphatase from Poa pratensis by binding to lectins, In: LectinsBiology, Biochemistry, Clinical Biochemistry, vol 1: Bøg-Hansen, T.C. ed. Walter de Gruyter, Berlin, New York, pp.157-167

LORENC-KUBIS I., MORAWIECKA B., WIECZOREK E., WIŚNIOWSKA J., WIERZBA E., FERENS M., BØG-HANSEN T.C.,1981. Effect of lectins on enzymatic properties. Plant acid phosphatases and ribonucleases. In: Lectins-Biology, Biochemistry, Clinical Biochemistry, vol 1 : Bøg-Hansen, ed., Walter de Gruyter, Berlin, New York, pp. 169-178

LORENC-KUBIS I., MORAWIECKA B., 1984. Acid phosphatase from stored Poa pratensis caryopses and its ability for binding to lectins Acta. Soc. Bot. Polon. 53: 205-213.

LORENC-KUBIS I., MORAWIECKA B., 1985. Post-synthetic modifications of proteins change during development. Acid phosphatases from different grass tissues. In: Lectins-Biology, Biochemistry, Clinical Biochemistry, vol 4: Bøg-Hansen, T.C., Bręborowicz, J., eds., Walter de Gruyter, Berlin, New York, pp. 259-266.

LORENC-KUBIS I., MORAWIECKA B.,1986. Acid phosphatase from grass tisues: II Con A-binding root acid phosphatase isoenzymes and their immunological relationship. In: Lectins-Biology, Biochemistry, Clinical Biochemistry, vol 5: Bøg-Hansen, T.C., van Driessche, E., eds. Walter de Gruyter, Berlin, New York, pp. 617622. 
LOWRY O.H., ROSEBROUGH N.J., FAR A.L., RANDALL R.J.,1951. Protein measurement with Folin phenol reagent. J. Biol. Chem.193: 265-275.

MIODUSZEWSKA H., BIELIŃSKA-CZARNECKA M.,1984. Influence of GA treatment on acid phosphatase activity in potato tubers towards the end of growth in dormancy and sprouting. Acta Physiol. Plantarum 6: 75-81.

MORAWIECKA B., ARABSKA E. 1982. Isolectins of Solanum tuberosum and their effect on potatoe tuber acid phosphatase. Contents of Vth Intr. Lectin Meeting, Bemo pp.126-127.

MORIS P.C., MADDOCK S.E., JONES M.G.K., BOWLES D.J 1985. Changes in the levels of wheat and barley-germ agglutinin during embryogenesis in vivo, in vitro and during germination. Planta 166: 407-413.

OUCHTERLONY O. 1967. Handbook of Experimental Immunology, Weir, D.M., ed. Blackwell Sci. Publ. Oxford and Edinburg pp. 655-706.
PICHE L., ACKERLEY C.A., PETRSON R.L.1985. Localization of L-Fucose in the root cap and slime of Zea mays L. Utilizing fluorescent lectin conjugates and colloidal gold-lectin techniques. Plant Sci. 40: 179-184.

TAMURA T., NINA KAWA T., KOSHIBA T. 1982. Acid phosphatase in cotyledons of germinating Vigna mungo seeds. Plant Cell Physiol.:115-159.

TENO A.M., PALM, M.S., ROSSI A. 1987. Acid phosphatase from maize scutellums: properties as a function of seed germination. Phytochemistry $26: 55-58$.

WILIMOWSKA-PELC A., DRYJAŃSKI, M., ŻAL T., WILUSZ T. I 1 991. Metallo-proteinase from the seedlings of kale (Brassica oleracea $L$ var.satellica): Preparation, partial characterization and substrate specificity. Planta 185: 344-349.

\section{KWAŚNE FOSFATAZY NASION I ROZWIJAJĄCYCH SIĘ SIEWEK DYNI FIGOLISTNEJ (CUCURBITA FICIFOLIA)}

\section{STRESZCZENIE}

Przeprowadzone badania nad kwaśnymi fosfatazami (AcPazami) liścieni dyni figolistnej wykazały zmiany aktywności enzymu w trakcie kiełkowania nasion i rozwoju siewk. Niską aktywność kwaśnej fofatazy stwierdzono w suchych nasionach jak i liścieniach w początkowym okresie kiełkowania. Wyraźny wzrost aktywności enzymu obserwowano w liścieniach 6 dniowych siewek. Z liściewni nasion oraz siewk 6-, 10-, 22dniowych izolowano kwaśne fosfatazy poprzez ekstrakcję białek $0.1 \mathrm{M}$ buforem octanowym o pH, 5.1, wytrącanie alkoholem oraz chromatografię powinowactwa na con A-Sepharose. We wszystkich przypadkach uzyskano dwie grupy glikoproteinowych enzymów: AcPazę Ba i AcPazę Bb różniące się powinowactwem do immobilizowanej lektyny. W kompleksie z wolną con A enzymy te zachowywały aktywność. W rakietowej elektroforezie powinowactwa AcPazy $\mathrm{Ba}$ i Bb izolowane z liścieni nasion oraz rozwijających się siewek wykazywały różnice w powinowactwie do wolnej con A świadczące o zmianach zachodzących w części węglowodanowej tych enzymów. Wydzielone enzymy wykazywały podobieństwo antygenowe $\mathrm{z}$ kwaśnymi fosfatazami roślin jednoliściennych - traw.

SŁOWA KLUCZOWE: Kwaśna fosfataza, powinowactwo do con A, liścienie, Cucurbitaceae, glikoproteiny, immunologiczne pokrewieństwo. 